\title{
The Political Economy of Financial Repression Policy-Dominated China's Overheated Housing Market
}

\author{
Anqi Lei \\ Department of Government and Public Administration, University of Macau, Macau, China \\ Email: sally50673462126.com
}

How to cite this paper: Lei, A. Q. (2017). The Political Economy of Financial Repression Policy-Dominated China's Overheated Housing Market. Chinese Studies, 6, 213233.

https://doi.org/10.4236/chnstd.2017.64021

Received: August 22, 2017

Accepted: October 23, 2017

Published: October 26, 2017

Copyright $\odot 2017$ by author and Scientific Research Publishing Inc. This work is licensed under the Creative Commons Attribution International License (CC BY 4.0).

http://creativecommons.org/licenses/by/4.0/

Open Access

\begin{abstract}
Chinese government has adopted financial repression policy for a very long time as a necessary step to stimulate domestic growth and help eliminate domestic and external risks. In China, a series of financial repression policies have been implemented, such as explicit or indirect capping of interest rates and protection of state-owned enterprises. However, its side effects are inevitable simultaneously. Under these financial repression policies, state-owned enterprises (SOEs), banks and governments could be the three biggest beneficiaries since they can easily get founds and profits to finance themselves through the policies while private and small firms are actually discriminated and can get very little benefit from the policy. At the same time, the long-term implementation of repression policy has triggered domestic housing speculation since 2008 when financial crisis caused by U.S subprime crisis swept the world, which then further fueled an expansion in debt that makes Chinese banks quite risky. Thus, in the past several years, the over high housing price and the huge amount of bank loans in real estate sector in China's real estate market has become a controversial topic and arouse people's attention all over the world. Policy makers and scholars are worried that China's overheated housing market may lead to bank debt crisis in the near future like the U.S. Therefore, in this paper, we tried to answer two main questions: What kinds of side-effects have been caused by China's financial repression policy after its economy boom? What kind of role did China's financial repression policies play in inducing its domestic overheated housing market? Is the bank credit, or debts problem induced by housing purchasing and investing severe enough to lead to a higher level of credit risk in China?
\end{abstract}

\section{Keywords}

Financial Repression Policy, Real Estate Market Overinvestment, Bank 
Potential Risks, SOEs and Private Firm Financing, Government

Administration

\section{Introduction}

China's financial repression policy has been adopted for a very long time since 1949, and even after 1978 China's reform and opening-up, to help create faster capital accumulation and stimulate development of industrialization and economics of China by curbing domestic consumption. Nevertheless, financial repression decisions proved to be double-edged. The related measures are quite efficient in stimulating economic development, such as, Chinese government impose high reserve requirements, very low deposit rate, and capital control. But the series of policies also led to unexpected results for domestic economy, especially in real estate sector. Previous cases of housing bubble, such as the United States before 2008 and Korea in the 1970s, demonstrate that the desire of regulators to eliminate domestic or external risk, by making financial decisions and formulating financial policies, would create new, or a high level of risk in real estate market.

In the past three decades, China's 10\% annual average economic growth could be largely attributed to financial repression, but the negative consequences rose at the same time in the following years, especially in real estate market. The over expansion of credit and rapid increase of money supply directly encouraged housing purchasing and then pushed up housing price dramatically. The report of ICBC (2008) shows that more and more developers and households start speculating in real estate market since the real estate loans rose dramatically in the past seven years.

Apparently, we cannot deny negative results caused by financial repression policies, and the embedded potential debt risk is pushing China into a more dangerous economic situation. Bloomberg's (2015) new report indicated China's loans to companies and households stood at a record $207 \%$ of gross domestic product at the end of June 2015 which was even higher than Greek debt (185\% of GDP). Thus, whether debt crisis will come up soon following the overheated housing market like the U.S and Asian countries has become a hot topic concerned by people all over the world.

\section{China's Financial Repression Policy}

In the past three decades, China's 10\% annual average economic growth could be largely attributed to financial repression thanks to the low saving rate paid to bank depositors usually failed to match the inflation rate, which made banks to be able to provide cheap loans to state enterprises (SOEs) and infrastructure investment. This has allowed China to rely on savings-financed investments for economic growth, and also allowed governments to finance themselves at artifi- 
cially low interest rates.

Giovannini \& De Melo (1990) regarded government-imposed controls on domestic financial markets, or the financial repression policies as a form of taxation and it actually made economic liberalization largely stopped at the gates of the financial sector. In China, since 1978 opening reform, although Chinese economy is more open to the world, repression policies are not abolished. As a matter of fact, investment funds are mainly channeled through state-owned banks to state-owned enterprises (SOEs), which then sacrifices many more efficient, small, entrepreneurial and private enterprises.

What's more, for Chinese households, there are few investment alternatives, stock markets are dominated by SOEs, and it is quite risky and opaque, bond markets are also controlled by the party instead of market-driven, deposit interest rates are set lower than inflation rate primarily by government, the capital flow is controlled and even forbidden strictly. All of these have stimulated Chinese households and enterprises to focus on real estate market expecting for higher rate of return than other markets. At the same time, financial repression policies also helped fuel an expansion in debt to levels evoking comparisons with the excesses that generated Japan's lost decade and the Asian financial crisis.

In China, central government adopted financial repression by typically setting nominal interest-rate ceilings that are well below the prevailing rate of inflation and currency depreciation. Table 1 shows the change of consumer price index (CPI) from 2008 to 2015 and Figure 1 illustrates the adjustment of RMB deposit rate of Bank of China during the same period. Apparently, RMB deposit rate always changes with the fluctuation of CPI, but is usually lower than the inflation rate, especially for the demand deposit and short-term time deposit. Peterson Institute (Lardy, 2008) measured Chinese repression policy in their report that "the one-year term deposit rate in the first quarter of 2008 was 4.14 percent, an increase of 2.16 percentage points from the rate in February 2002. But that increase is less than a fourth of the increase in the pace of inflation over the same period and has converted a real return of 2.78 percent in 2002 into a real return of -3.86 percent in the first quarter of 2008 ".

Borst \& Lardy (2015) even argue that the interest rate established by the People's bank of China for the whole banking system actually implies a hidden tax on household savings which equals "more than three times the proceeds from the only tax imposed directly on households-the personal income tax". According to the calculation of Peterson Institute (Lardy, 2008) in their report,

Table 1. CPI from 2008 to 2015.

\begin{tabular}{ccccccccc}
\hline Year & 2008 & 2009 & 2010 & 2011 & 2012 & 2013 & 2014 & 2015 \\
\hline CPI (last year = 100) & 105.9 & 99.3 & 103.3 & 105.4 & 102.6 & 102.6 & 102 & 101.2 \\
CPI $(1978=100)$ & 522.7 & 519 & 536.1 & 565 & 579.7 & 594.8 & 606.7 & 615.2 \\
\hline
\end{tabular}

Source: National bureau of statistics of china. 


\begin{tabular}{|c|c|c|c|c|c|c|c|}
\hline Date & Dem and depos Tim e deposit\% & $3 \mathrm{~m}$ on ths & $6 \mathrm{~m}$ on ths & 1 year & 2 year & 3 year & 5 year \\
\hline 2008.10 .9 & 0.72 & 3.15 & 3.51 & 3.87 & 4.41 & 5.13 & 5.58 \\
\hline 2008.10 .30 & 0.72 & 2.88 & 3.24 & 3.6 & 4.14 & 4.77 & 5.13 \\
\hline 2008.11 .27 & 0.36 & 1.98 & 2.25 & 2.52 & 3.06 & 3.6 & 3.87 \\
\hline 2008.12 .23 & 0.36 & 1.71 & 1.98 & 2.25 & 2.79 & 3.33 & 3.6 \\
\hline 2010.10 .20 & 0.36 & 1.91 & 2.2 & 2.5 & 3.25 & 3.85 & 4.2 \\
\hline 2010.12 .26 & 0.36 & 2.25 & 2.5 & 2.75 & 3.55 & 4.15 & 4.55 \\
\hline 2011.2 .9 & 0.4 & 2.6 & 2.8 & 3 & 3.9 & 4.5 & 5 \\
\hline 2011.4.6 & 0.5 & 2.85 & 3.05 & 3.25 & 4.15 & 4.75 & 5.25 \\
\hline 2011.7.7 & 0.5 & 3.1 & 3.3 & 3.5 & 4.4 & 5 & 5.5 \\
\hline 2012.6 .8 & 0.44 & 3.1 & 3.3 & 3.5 & 4.1 & 4.65 & 5.1 \\
\hline 2012.7 .6 & 0.35 & 2.85 & 3.05 & 3.25 & 3.75 & 4.25 & 4.75 \\
\hline 2014.11 .22 & 0.35 & 2.6 & 2.8 & 3 & 3.5 & $\square 4$ & 4.25 \\
\hline 2015.3 .1 & 0.35 & 2.35 & 2.55 & 2.75 & 3.25 & 3.75 & 4 \\
\hline 2015.5.11 & 0.35 & 2.1 & 2.3 & 2.5 & 3 & 3.5 & 3.75 \\
\hline 2015.6 .28 & 0.35 & 1.85 & 2.05 & 2.25 & 2.75 & 3.25 & 3.35 \\
\hline 2015.8 .26 & 0.35 & 1.6 & 1.8 & 2 & 2.5 & 3 & 3.05 \\
\hline 2015.10 .24 & 0.3 & 1.35 & 1.55 & 1.75 & 2.25 & 2.75 & 2.75 \\
\hline
\end{tabular}

Figure 1. Deposit rate of bank of china from 2008 to 2015. Source: bank of china.

"household deposits at the end of the first quarter of 2008 stood at RMB 19.1 trillion while their bank borrowings stood at RMB 5.3 trillion, making their net deposits RMB 13.8 trillion. The estimated implicit tax on these deposits is RMB 255 billion ( $\$ 36$ billion), the equivalent of 4.1 percent of GDP, in the first quarter of 2008 ". This implicit tax was actually more than three times the government revenue from the personal income tax which was only 1.3 percent of GDP in 2007.

As we mentioned above, financial repression policies originally come of government-led policy (Lardy, 2008; Johansson, 2012), and were initially adopted by Chinese government to help create faster capital accumulation and stimulate development of industrialization and economics by curbing domestic consumption through very low deposit interest. Johansson (2012) gave another explanation on the form of financial repression policies in emerging countries, including China, which put the blame on "developed-country central bank policy based on "zero-bound" interest rates". He argues that emerging market economies have no choice but to control capital inflow and excessively lower domestic deposit interest rate because many developed-country central bank, such as European Central Bank, the Bank of England, and the Bank of Japan, have followed the U.S. Federal Reserve's to put downward pressure on long rates. They these emerging market economies did not do so, they "would lose monetary control as foreign hot money poured in the recipient emerging market government would be forced [to] intervene to prevent its exchange rate from appreciating precipitously" (Schnabl, 2012).

However, China is not the first country to adopt financial repression policy to motivate domestic economic development. Korea has actually experienced significant periods of financial repression in the 1970s which also played an important role in their overheated housing market. Korea's economic growth greatly relied on "strong directed credit policies". They include "favoring the commercial banking system while suppressing private bond and equity markets. Then governments impose high reserve requirements and rely on the obligatory holding of government bonds to tap savings at low interest rates or zero cost to the 
public sector" (Renaud, 1988: 4). As a result, opposite to government's original expectation, instead of mobilizing household savings, the real estate market in Korea had become a substitute for the equity market and the holding of financial assets. The implementation of financial repression policy has generated significant distortions in Korean housing sector, and "the speed of real estate appreciation was a massive 14 percent compounded real rate during the period 1963-1974" since "the behavior of households and their desire to accumulate wealth" is the main point through which financial policies and urban investment could be connected. Housing provides the dominant saving instrument for most families in developed economies, and it is the even more important saving instrument in developing countries (Renaud, 1988).

China's current situation and financial repression policy and the case of Korea in 1970s are quite alike to some extent. To encourage large and state-owned enterprises and finance government itself to support public expenditure, Chinese government also adopt a series of financial and monetary policies. The low real interest rate and strict capital control, combined with suppression of private bond and equity market, all together encouraged domestic households to increase their wealth accumulation by investing in housing market. One main difference of China's financial market from Korea's is the great amount of credit availability of banks. For Chinese households, mortgage loans from banks is their main source of financing for house purchasing, which actually further motivates house buying in the market. Therefore, we cannot deny the negative consequences of financial repression policies and the similarity of real estate speculation caused by financial repression, although it has been the engine for the whole economic growth.

\section{Results of Financial Repression Policy}

\subsection{Corporates, Banks, and the Government are the Biggest Beneficiaries}

First of all, corporates, especially state-owned enterprises (SOE) might benefit most from financial repression policies. As a matter of fact, a great amount of low-yielding household savings, usually at state-owned banks, flow into least efficient SOEs and politically favored investment projects with low returns, but usually at the expense of the more efficient small, entrepreneurial and private enterprises.

Investment funds are mainly channeled through state-owned banks to state-owned enterprises (SOEs). Peterson Institute (Lardy, 2008) pointed out the dramatic drop of the real interest rate for corporate borrowers from $7.6 \%$ in 2002 to $-0.5 \%$ in 2008 , which provided corporate borrowers with a reduce of $8.1 \%$ points of one-year loans in 2008 than in 2002. This provided corporates with a huge amount of implicit subsidy (22.2 trillion RMB), even far more than the implicit tax imposed on households. While those SOEs produce "less than one-third of industrial output value", they are able to receive "two-thirds of the commercial credit flowing through state-owned banks". Thus, a great waste of 
money could be seen due to the lack of transparency and the politicization of the lending process, and China's high share of nonperforming loans (NPL) could exactly reflect this fact (Dorn, 2006). Although large state-owned banks, medium-sized joint-stock commercial banks and city commercial banks, such as Bank of China and Industrial and Commercial Bank of China all announced their NPL ratio as above or below 1 in recent years (See Table 2), IMF (2016) reported China's debt-at-risk at 15\% in their Global Financial Stability report. Bloomberg (2015) also showed the quickly increasing amount of nonperforming loans of China's bank from 2009 to 2015 (Figure 2).

SOEs can easily get founds from large state-owned banks, but private enterprises in non-state sector can get very little. The World Business Environment Survey (WBES) 2000 (Batra, Kaufmann, \& Stone, 2002), conducted by the World Bank, found that China has the highest percentage of non-state firms subject to major financing constraints among all the 7 selected Asian countries. Around $66.3 \%$ of the Chinese firms in non-state sector were stuck in a major obstacle in 1999-2000 based on the general financing constraint (GFC) results (Figure 3). Figure 4 shows the share of state bank lending to non-state sector (around only 10\%) from 1997 to 2001. Although data of following years are not published by the PBOC any more, an enterprise survey conducted by The World Bank (2012) (Figure 5) summarized the biggest obstacles experienced by private sector firms in China. In this survey, business owners and top managers in 2,700 Chinese firms were interviewed, and the result shows that the access to finance is still the biggest obstacle for firms in non-state sector. Related finance indicators of Chinese firms published by The World Bank (2012) also show that it is quite hard for Chinese private firms to get financial support from banks (Table 3). Among Chinese private firms, the percent of firms with a bank loan is only $25.3 \%$, lower than the average indicator of East Asia \& Pacific (27.9\%) and the average indicator of all countries (33.8\%). Similarly, the percent of firms using banks to finance investments (14.7\%) and the percent of firms using banks to finance working capital (22.1\%) are all much lower than the world average indicator (25.3\% and 30.4\%). For private enterprises, most of their investments are mainly financed by internal funds (89.6\%),

Table 2. NPLS ratio of China's biggest five banks.

\begin{tabular}{lcc}
\hline \multicolumn{1}{c}{ Chinese Bank } & $\begin{array}{c}\text { NPLs Ratio at the End of } \\
\text { June 2014 (\%) }\end{array}$ & $\begin{array}{c}\text { NPLs Ratio at the } \\
\text { End of 2013 (\%) }\end{array}$ \\
\hline Bank of China & 1.02 & 0.96 \\
Industrial and Commercial Bank of China & 0.99 & 0.94 \\
Agricultural Bank of China & 1.24 & 1.08 \\
China Construction Bank & 1.04 & 0.99 \\
Bank of Communications & 1.13 & 1.05 \\
Banking Industry Average & 1.08 & 1.00 \\
\hline
\end{tabular}

Source: Government UK (2014). 


\section{China Banks' Bad Loans in Billions of Yuan}

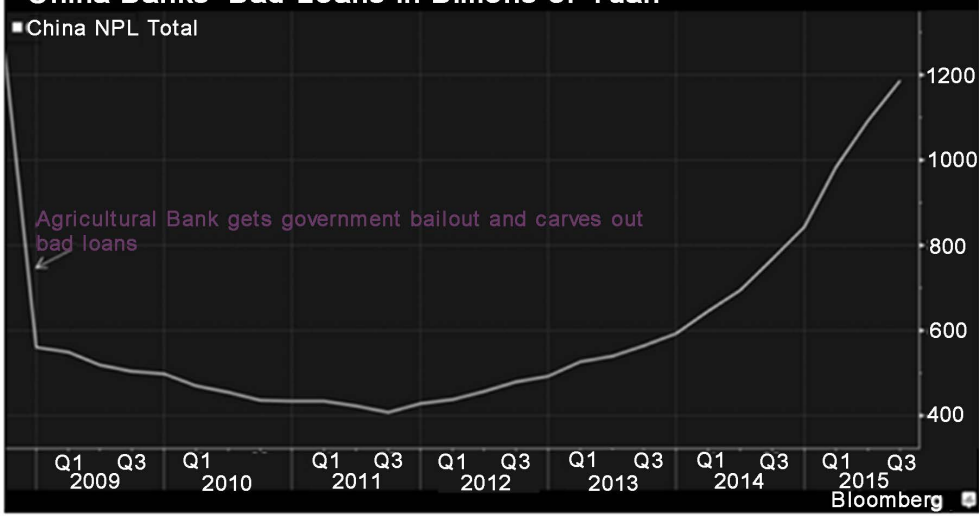

Figure 2. NPLS ratio of China's banks from 2009 to 2015. Source: Bloomberg (2015).

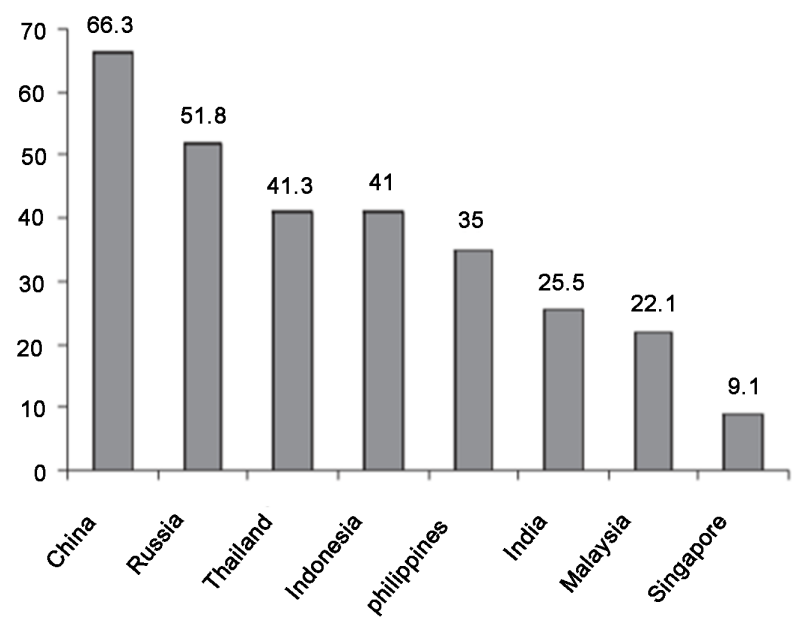

Figure 3. The percentage of non-state firms subject to major financing constraints among 7 selected Asian countries. Source: Dorn, (2006: 2) based on World Bank, "World Business Environment Survey (WBES) 2000” (Batra, Kaufmann, \& Stone, 2002).

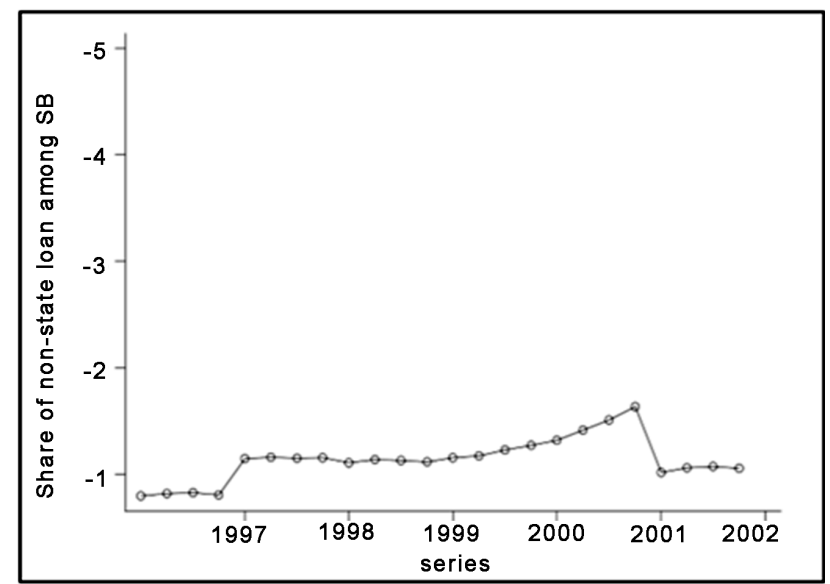

Figure 4. The share of state bank lending to non-state sector. Source: Shih, 2004. 


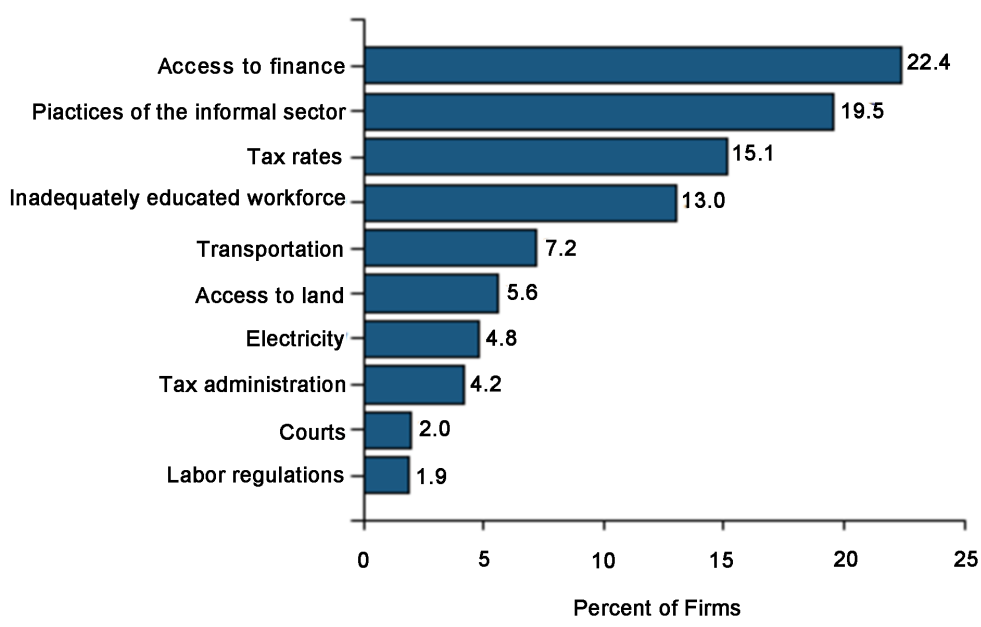

Figure 5. Ranking of the top business environment obstacle for firms. Source: The World Bank, 2012.

Table 3. Indicators of Chinese private firms financing.

\begin{tabular}{lccc}
\hline \multicolumn{1}{c}{ Indicator } & China & $\begin{array}{c}\text { East } \\
\text { Asia \& } \\
\text { Pacific }\end{array}$ & $\begin{array}{c}\text { All } \\
\text { Countries }\end{array}$ \\
\hline Percent of firms with a bank loan/line of credit & 25.3 & 27.9 & 33.8 \\
Percent of firms using banks to finance investments & 14.7 & 20.2 & 25.3 \\
Proportion of investments financed internally (\%) & 89.6 & 77.8 & 71.2 \\
Proportion of investments financed by banks (\%) & 4.5 & 10.2 & 14.3 \\
Proportion of investments financed by supplier credit (\%) & 1.9 & 3.2 & 4.7 \\
Proportion of investments financed by equity or stock sales (\%) & 3.2 & 3.4 & 4.8 \\
Percent of firms using banks to finance working capital & 22.1 & 24.9 & 30.4 \\
Proportion of working capital financed by banks (\%) & 6.4 & 10.2 & 11.6 \\
Proportion of working capital financed by supplier credit (\%) & 4.4 & 7.1 & 10.6 \\
\hline
\end{tabular}

Source: The World Bank, 2012.

and this number is much higher than the average indicator of East Asia \& Pacific (77.8\%) and the average indicator of all countries (71.2\%).

Banks themselves are one of the beneficiaries of financial repression policies because customer deposit is still the Bank's main source of fund. For example, at the end of 2008, the balance of due to customers of the Industrial and Commercial Bank of China (ICBC) (which is China's largest bank) was 8,223,446 million yuan, which contributed $89.9 \%$ of the total liabilities. And due to the effect of global financial crisis and the downturn of stock market in 2008, the growth of savings deposits was greatly stimulated and went up dramatically by $23.6 \%$ from the previous year to RMB 4,010,248 million in that year, which of course provided a huge amount of money as fundamental resources for banks (ICBC Annual Report, 2008). In recent years, banks still mainly replied on customer depo- 
sit to support their business and operation. In 2014, in order to attract more deposit in the increasingly fierce market competition, ICBC gave full play to its comprehensive edges in financial services, improved the differential pricing mechanism of deposit interest rate and reinforced marketing for deposits. At the end of 2014, the balance of due to customers was RMB 15,556,601 million, and net interest income of ICBC was RMB 493,522 million which took up $77.7 \%$ of the Bank's operating income. Interest income on loans and advances to customers was RMB 615,488 million, RMB 66,848 million or $12.2 \%$ higher than that of the previous year, the benchmark interest rate cut in November 2014 had slight impact on interest income on loans and advances to customers in 2014 (ICBC Annual Report, 2014). Thus, there is no doubt that customer deposits play a very important role in China's banks since the large amount of customer deposits assured that banks have abundant funds to lend money and make profit accordingly.

The newest data of 2016 shows that, maintaining the leading position, the ICBI had the domestic new RMB deposits of RMB 1280.2 billion, representing a year-on-year increase of RMB 610.2 billion, hence achieving the highest of the last three years. What's more the balance of RMB deposits amounted to RMB $16,722,751$ million in year 2016 , which accounted for $93.8 \%$ of the total balance of due to customers, and the balance of foreign currency deposits was amounted to $\mathrm{RMB} 1,102,551$ million, 30.3\% over the previous year (ICBC Annual Report, 2016).

But Lardy (2008) pointed out in his report that banks are not the largest beneficiaries of financial repression. Although Chinese banks "gain from access to low-cost deposits but lose from the requirement to place funds into low-yielding reserves and central bank bills". Commonly, the central bank uses two main instruments to sterilize increases in the domestic money supply. One is to increase the required reserve ratio of banks in order to ensure the stability of domestic money supply. At the beginning, to maintain a fixed nominal exchange rate vis-à-vis the US dollar control the pace of renminbi appreciation, the central bank has been forced to intervene massively in the foreign currency market. In 2006, our official foreign exchange reserves amounted to 853.7 billion dollars, which ranked first in the world. Quickly, it increased to 2.85 trillion dollars in 2010 and 3.89 trillion dollars in 2014. To prevent the oversupply of domestic money supply, the PBC increased the required reserve ratio of banks 15 times from 2007 to the end of June 2008, taking the rate from $9.5 \%$ to $17.5 \%$. After peaked at $17.5 \%$ in June 2008 , the PBC quickly decreased the reserve ratio to stimulate domestic purchasing and investment to offset the influence of global financial crisis. But again, since May 2010, the reserve requirement ratio was increased from $13.5 \%$ to $18 \%$ in June 2011 , which made banks to place much more amount of money on deposit at the central bank which, however, gives very low yields (PBC Annual Report, 2010).

Selling large quantities of central bank bills to banks is another important instrument for central bank to control domestic money supply. At the end of June 
2008 banks held RMB 4.2 trillion in central bank bills (Lardy. 2008). The data of ICBC shows that the bank made major investment in central bank bill especially before 2011. In fact, this sale of central bank bills as a type of sterilization also imposes a tax on banks. For instance, according to the calculation and analysis of Lardy (2008: 3), "three-year bills sold at the end of June 2008 yield 4.56 percent, far less than the 7.75 percent benchmark interest rate on a three-year loan", which made banks bear 230 billion RMB implicit tax through holding additional low-yielding reserves and central bank bills in 2007. The annual report of ICBI in recent years demonstrate a dramatic downward trend of central bank bill purchasing and an upward trend of government bond purchasing, especially after 2011 (see Table 4). Apparently, the Bank made heavy investment in central bank bills in previous years, and the amount of central bank bill was 797.024 billion yuan (about $38.6 \%$ of total ICBC investment in securities) in 2008 , but the share of central bank bill decreased year by year at $20.1 \%$ ( 682.676 billion yuan) in 2011 , and $10.2 \%$ (289.662 billion yuan). In 2014 , the share was only $8.7 \%$ of total investment in securities, and the official explanation for the drop of central bank bill was the maturity of part of the central bank bills during the reporting period. It is clear that central bank bills decreased by RMB 298,401 million or 83.7\% from 2015 to 2016. Meanwhile, the Bank stepped up the investment in local government bonds (48.1\% in 2016) and treasury bonds in order to support the development of real economy under the influence of changes in normal maturity of bonds and supply structure of the bond market. According to the table, the percentage of government bond purchasing among total investment in securities increased dramatically from $20.5 \%$ in 2008 to $48.1 \%$ in 2016 .

Table 4. Distribution of investment in securities not related to restructuring by issuer.

\begin{tabular}{|c|c|c|c|c|c|c|}
\hline Year & (Million yuan) & $\begin{array}{l}\text { Government } \\
\text { bonds }\end{array}$ & $\begin{array}{c}\text { Central bank } \\
\text { bills }\end{array}$ & $\begin{array}{l}\text { Policy bank } \\
\text { bonds }\end{array}$ & $\begin{array}{l}\text { Other } \\
\text { bonds }\end{array}$ & Total \\
\hline 2008 & $\begin{array}{l}\text { Amount } \\
\text { percentage }\end{array}$ & $\begin{array}{c}422,585 \\
20.5 \%\end{array}$ & $\begin{array}{c}797,024 \\
38.6 \%\end{array}$ & $\begin{array}{c}601,127 \\
29.1 \%\end{array}$ & $\begin{array}{c}243,245 \\
11.8 \%\end{array}$ & $2,063,981$ \\
\hline 2009 & $\begin{array}{l}\text { Amount } \\
\text { percentage }\end{array}$ & $\begin{array}{c}570,952 \\
21.2 \%\end{array}$ & $\begin{array}{c}967,146 \\
35.8 \%\end{array}$ & $\begin{array}{c}759,010 \\
28.1 \%\end{array}$ & $\begin{array}{c}402,146 \\
14.9 \%\end{array}$ & $2,699,254$ \\
\hline 2010 & $\begin{array}{l}\text { Amount } \\
\text { percentage }\end{array}$ & $\begin{array}{c}728,399 \\
21.9 \%\end{array}$ & $\begin{array}{c}1,184,717 \\
35.7 \%\end{array}$ & $\begin{array}{c}977,903 \\
29.4 \%\end{array}$ & $\begin{array}{c}431,896 \\
13 \%\end{array}$ & $3,322,915$ \\
\hline 2011 & $\begin{array}{c}\text { Amount } \\
\text { percentage }\end{array}$ & $\begin{array}{c}858,194 \\
25.2 \%\end{array}$ & $\begin{array}{c}682,676 \\
20.1 \%\end{array}$ & $\begin{array}{c}1,318,582 \\
38.7 \%\end{array}$ & $\begin{array}{c}543,343 \\
16 \%\end{array}$ & $3,402,795$ \\
\hline 2012 & $\begin{array}{c}\text { Amount } \\
\text { percentage }\end{array}$ & $\begin{array}{c}875,876 \\
23.5 \%\end{array}$ & $\begin{array}{c}553,216 \\
14.9 \%\end{array}$ & $\begin{array}{c}1,587,949 \\
42.7 \%\end{array}$ & $\begin{array}{c}702,261 \\
18.9 \%\end{array}$ & $3,719,302$ \\
\hline 2013 & $\begin{array}{c}\text { Amount } \\
\text { percentage }\end{array}$ & $\begin{array}{c}976,351 \\
25.4 \%\end{array}$ & $\begin{array}{c}289,662 \\
10.2 \%\end{array}$ & $\begin{array}{c}1,682,619 \\
43.9 \%\end{array}$ & $\begin{array}{c}788,363 \\
20.5 \%\end{array}$ & $3,836,995$ \\
\hline 2014 & $\begin{array}{c}\text { Amount } \\
\text { percentage }\end{array}$ & $\begin{array}{c}1,026,985 \\
25.8 \%\end{array}$ & $\begin{array}{c}346,154 \\
8.7 \%\end{array}$ & $\begin{array}{c}1,687,791 \\
42.4 \%\end{array}$ & $\begin{array}{c}917,635 \\
23.1 \%\end{array}$ & $3,978,565$ \\
\hline 2015 & $\begin{array}{c}\text { Amount } \\
\text { percentage }\end{array}$ & $\begin{array}{c}1,468,674 \\
32.3 \%\end{array}$ & $\begin{array}{c}356,425 \\
7.8 \%\end{array}$ & $\begin{array}{c}1,513,092 \\
33.3 \%\end{array}$ & $\begin{array}{c}1,210,496 \\
26.6 \%\end{array}$ & $4,548,687$ \\
\hline 2016 & $\begin{array}{c}\text { Amount } \\
\text { percentage }\end{array}$ & $\begin{array}{c}2,399,463 \\
48.1 \%\end{array}$ & $\begin{array}{c}58,024 \\
1.2 \%\end{array}$ & $\begin{array}{c}1,319,450 \\
26.5 \%\end{array}$ & $\begin{array}{c}1,205,839 \\
24.2 \%\end{array}$ & $4,982,776$ \\
\hline
\end{tabular}

Source: ICBC Annual Year Report, 2008-2016. 
The related data and calculations imply that the government, acting through the central bank and its sterilization operations, must be the largest beneficiary of the financial repression. Lardy (2008: 4) argued that the government captured slightly more than half of the implicit net tax imposed on households by financial repression. The government is able to spend less maintaining a fixed and undervalued exchange rate through the central bank than adopting a more liberalized interest rate mechanism. If adopting liberalized exchange rate, the government has to pay more for sterilization operation, which will "put greater pressure on the authorities to allow the exchange rate to appreciate so as to reduce the external surplus, thus reducing both the needed amount of intervention in the foreign exchange market and the needed magnitude of sterilization operations".

\subsection{Real Estate Market Overinvestment}

In fact, the changes in domestic and overseas economic environment in 2008 led to a quick drop in the demand for personal housing loans. In order to motivate domestic real estate market, many banks took some measures to motivate their loan business, and real estate market became the target market. Most of Chinese banks determine the amount and type of mortgage to be obtained on the basis of the credit risk evaluation of counterparties. Collaterals are provided in the form of bills, loans or securities for reverse repurchase agreements, in the form of real estates and other assets for commercial loans, and in the form of residential properties for personal loans. For instance, The ICBC "stepped up the support for residents buying house for own use, drove personal mortgage loans using real estate development loans, and strengthened cooperation with large high-quality real estate intermediary agencies to promote new housing and secondhand housing loan business" (ICBC Annual Report, 2008: 58). By the end of 2008, loans secured by mortgages amounted to RMB 1,688,435 million, including RMB 597,374 million personal housing loans and representing an increase of RMB 168,687 million or $11.1 \%$ over 2007 , which remained as the largest component of the total loans (Figure 6).

Quickly, the real estate loans in 2009 rose by RMB 95,137 million or $27.8 \%$, principally when more and more developers and households start speculating in real estate market. And during the period between 2008 and 2010, the percentage of corporate real estate loans was always above $10 \%$ until 2011 when the property loans began to decrease quickly by RMB 7306 million or $1.4 \%$, mainly because the Bank actively reduced the size of property loans in line with the changes in the real estate market (Figure 7). In fact, in 2011 many banks strengthened risk management of the real estate industry in response to the changes in relevant government policies which aimed to combat speculation in housing market. Thus, banks adjusted their credit policy for the real estate industry in a timely fashion, revised relevant administrative measures and further improved the property loan system. Banks, like ICBC, even improved their customer entry standards and "adjusted the product mix of property loans to extend 


\begin{tabular}{|c|c|c|c|c|}
\hline DISTRIBUTION OF LOANS BY COLLA & & $\ln \mathrm{R}$ & illions, exce & percentages \\
\hline \multirow[b]{2}{*}{ Item } & \multicolumn{2}{|c|}{ At 31 December 2008} & \multicolumn{2}{|c|}{ At 31 December 2007} \\
\hline & Amount & $\%$ of total & Amount & $\%$ of total \\
\hline Loans secured by mortgages & $1,688,435$ & 36.9 & $1,519,748$ & 37.3 \\
\hline Including: Personal housing loans(1) & 597,374 & 13.1 & 536,331 & 13.2 \\
\hline Pledged loans & 676,129 & 14.8 & 575,598 & 14.1 \\
\hline Including: Discounted bills(1) & 326,315 & 7.1 & 252,103 & 6.2 \\
\hline Guaranteed loans & 866,129 & 18.9 & 836,476 & 20.6 \\
\hline Unsecured loans & $1,341,301$ & 29.4 & $1,141,407$ & 28.0 \\
\hline Total & $4,571,994$ & 100.0 & $4,073,229$ & 100.0 \\
\hline
\end{tabular}

Figure 6. Distribution of loans by collaterals. Source: ICBC Annual Report, 2008.

\section{Corporate loans and non-performing corporate loans in real estate industry}

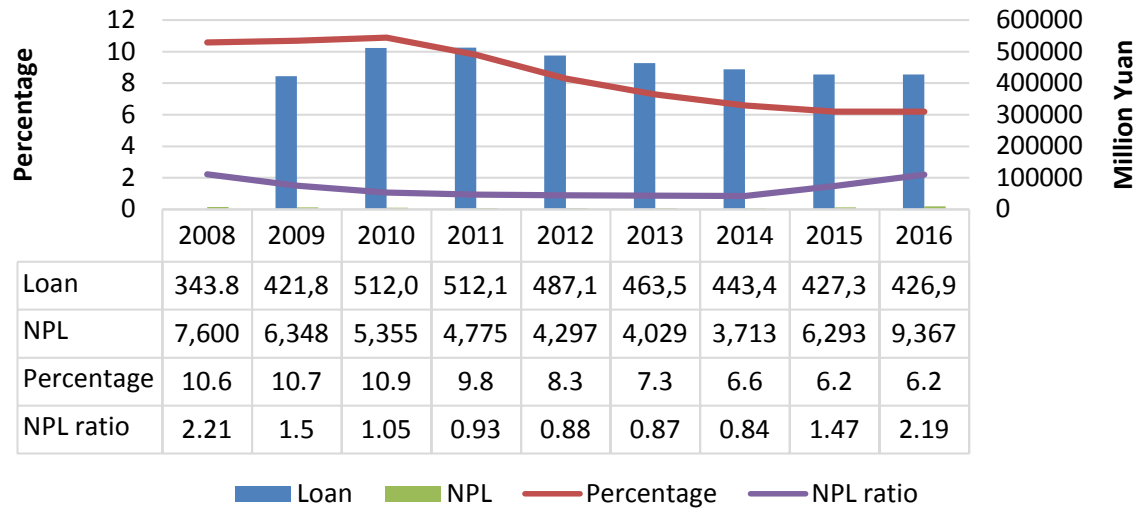

Figure 7. Corporate loans and non-performing corporate loans in real estate industry from 2008 to 2016. Source: ICBC Annual Report, 2008-2016.

an active support to the construction of government-subsidized housing and further improve relevant policy for land reserve loans" (ICBC Annual Report, 2011). These bank policies worked and since 2011, both corporate loans and non-performing ratio decreased obviously. By the end of 2014, the corporate loans only took up $6.6 \%$ of the total corporate loans among all industry.

However, one big problem is that the non-performing ratio increased quickly since 2014 , and it increased from $6.6 \%$ in 2014 to $2.19 \%$ in 2016 . As we can see in Table 5, the total loans and advanced to customers increased since 2008 and suddenly dropped since 2011 due to government real estate control policy, but again, it climbed quickly since 2014 and peaked at RMB 642,423 million in 2016 which is the highest in the history. We can also see from the table that there was huge amount of overdue loans in real estate sector in 2015 and 2016 at RMB 17,653 million and RMB 22,288 million, respectively, which was around 4 times more than that in year 2011, and even higher than the climax of 2009. What's more, loans that assessed to be impaired were amounted to as high as RMB 9556 million hence achieving the highest of the last ten years. All these data indicate that Chinese banks, represented by ICBC as the largest commercial state-owned bank in China, are and will face much severer default problem from real estate 
Table 5. Loans and advances to customers analysis in real estate sector from 2008 to 2016.

\begin{tabular}{ccccc}
\hline (Unit: million RMB) & $\begin{array}{c}\text { Gross loans and } \\
\text { advances to } \\
\text { customers }\end{array}$ & $\begin{array}{c}\text { Loans and } \\
\text { advances covered } \\
\text { by collateral }\end{array}$ & $\begin{array}{c}\text { Overdue loans } \\
\text { and advanced } \\
\text { to customers }\end{array}$ & $\begin{array}{c}\text { Loans and } \\
\text { advances } \\
\text { individually } \\
\text { assessed to be } \\
\text { impaired }\end{array}$ \\
\hline 2008 & - & - & - & - \\
2009 & 474,710 & 331,231 & 6922 & 7097 \\
2010 & 586,654 & 441,884 & 5987 & 5724 \\
2011 & 577,563 & 445,779 & 5306 & 5096 \\
2012 & 562,563 & 444,353 & 6704 & 4691 \\
2013 & 530,600 & 425,202 & 5169 & 4480 \\
2014 & 530,103 & 406,577 & 6213 & 4198 \\
2015 & 562,917 & 398,193 & 17,653 & 6434 \\
2016 & 642,423 & 423,175 & 22,288 & 9556 \\
\hline
\end{tabular}

Source: ICBC Annual Report, 2008-2016.

sector in the following years. And things for banks will become worse if China's real estate market began to cycle from boom to burst. Unfortunately, the housing market in many cities has already been cooled down in recent years.

\subsection{Potential Debt Crisis}

In China, out of their expectation, this form of financial repression policies caused large debt expansion and hot money in speculation industry, especially real estate market. On the one hand, low international interest rates have fueled debt through onshore banks. The IMF (2013) finds that Chinese state-owned banks have served as intermediaries for corporate borrowing overseas through the provision of bank guarantees and letters of credit. The IMF notes: "Chinese firms have also taken advantage of low global interest rates through offshore bond issuance, which has increased substantially since 2010. Half of the debt issued abroad has been for operations in China. Since 2009, real estate developers have been the largest issuers of offshore bonds among nonfinancial firms."

According to the statistics and calculation of a report from McKinsey Global Institute (Dobbs et al., 2015), non-financial corporations are most heavily indebted where real estate industry is a very significant part. As can be seen in Figure 8, the overall indebtedness of non-financial corporations increased dramatically from 72 trillion dollars in 2007 to 125 trillion dollars in 2014. At the same time, the debts of financial corporations and government also grew by a large amount since 2000, 828\% and 139\% respectively. According to Miriam's calculation (Campanella, 2016), "debt accumulation in areas such as real estate, shadow banking, provincial governments and SOEs has nearly quadrupled since 2007 , rising to US $\$ 28$ trillion by mid-2014, up from US $\$ 7$ trillion in $2007 ”$. Data compiled by Bloomberg (2015) shows that loans to companies and households 


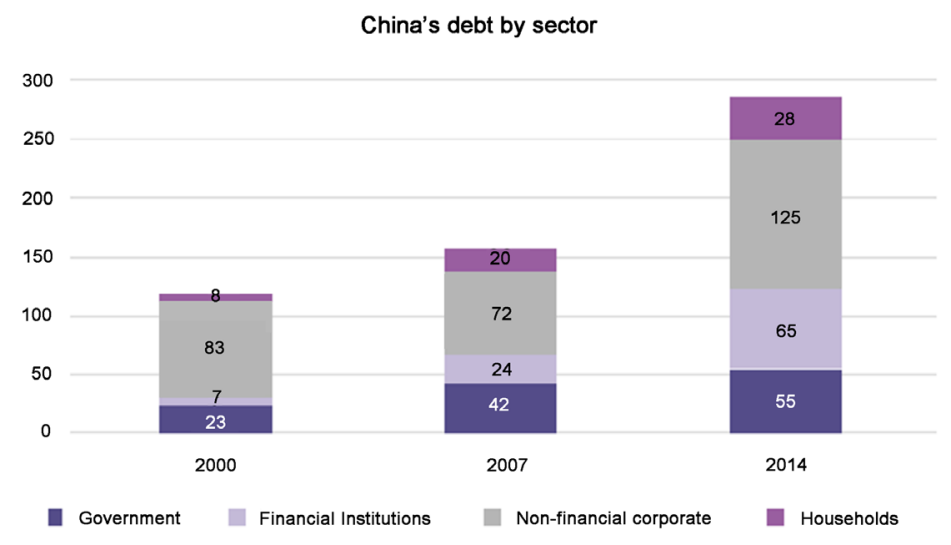

Figure 8. The composition of debt in China. Source: Dobbs et al., 2015.

stood at a record $207 \%$ of gross domestic product at the end of June 2015 which was even higher than Greek debt (185\% of GDP).

Figure 9 describes China's debt situation compared with South Korea, Australia, United States, Germany and Canada in 2014. Among all these countries, China's debt took up about 282 percent of GDP and listed number two, followed South Korea (286\% of GDP), but is larger than that of the United States, Australia, Canada and Germany. What's more, among all the six counties and four debt sectors, China had the largest amount of non-financial corporation debts, which is around twice as much as that of the United States, Canada and Germany. China also had the second largest amount of financial corporation debts, but least amount of household debts, only about half of that of the United States.

Figure 10 is about corporate debt in China in 2014 which shows that corporate debt in China has grown faster than in any other top-15 economy, and has become the highest in world's large economies, implying a potential government contingent liability.

Thus, the evidence has already demonstrated a severe debt expansion problem in China, and these financial or non-financial companies and enterprises may default at any time as economic growth began to slow down and housing bubble began to burst in many cities. A Bloomberg article investigated the related debt environment and potential risk in China and pointed out that "Firms now take record 192 days to collect payment for their goods or services from when they pay for the inputs, according to data compiled by Bloomberg on non-financial corporations traded in Shanghai and Shenzhen. The cash conversion ratio is up from 125 days five years ago. Liquidity is tightening in China after company profits declined for the first time in three years and as debtors face their hardest time ever paying interest". And the article quote Iris Pang of Natixis "the longer the cash conversion cycle, the higher the risk of corporates not having enough cash to repay their debts" (Bloomberg, 2016).

\subsubsection{Real Estate Industry Default Cases in China}

In China, debt exposure problems are just getting bigger. Many enterprises, especially real estate developers and related industries have been unable to pay 
Debt by Sector, 2014

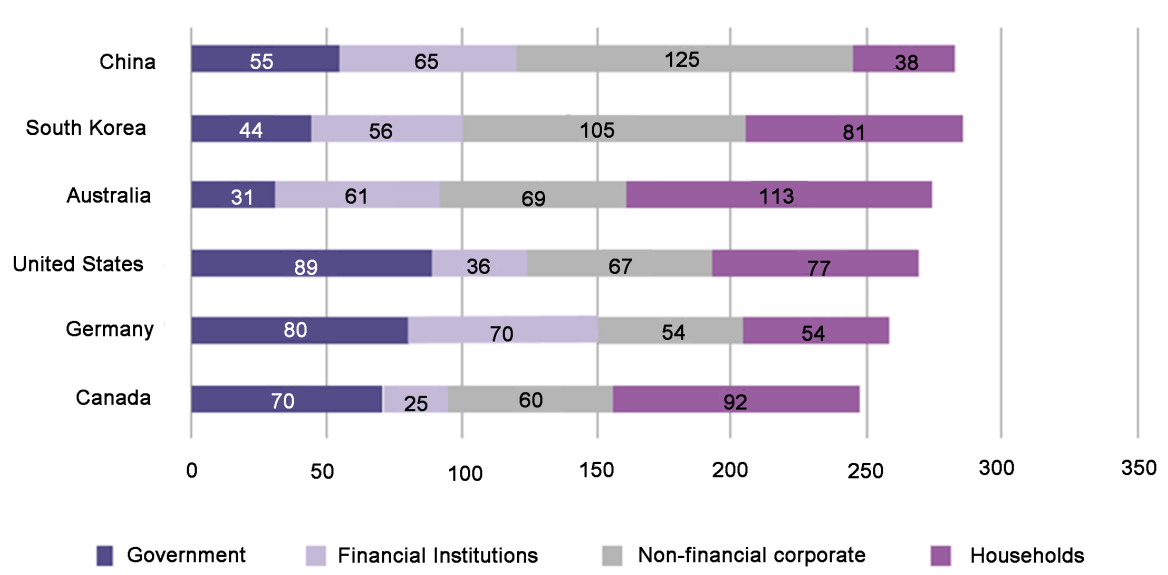

Figure 9. Chin's debt compared with selected economies. Source: Dobbs et al., 2015.

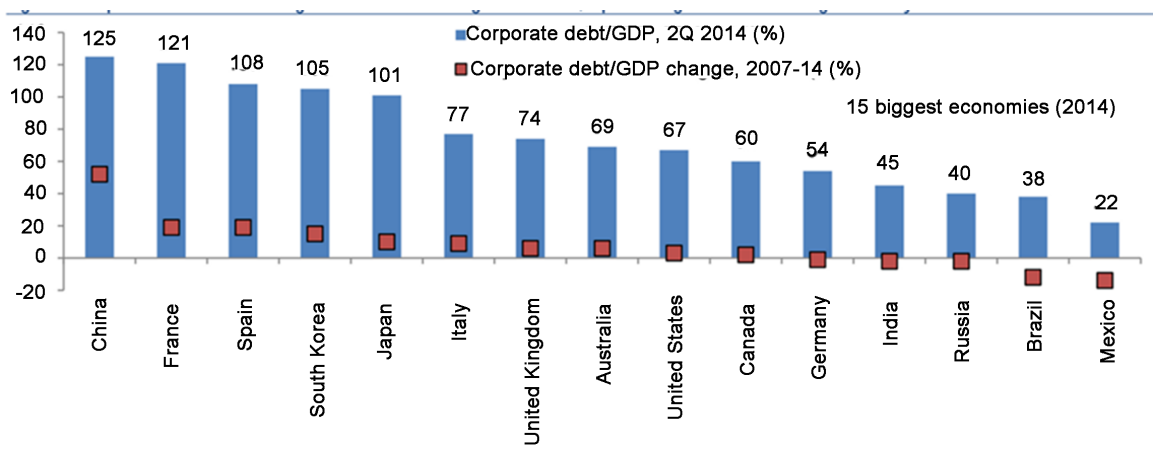

Figure 10. Corporate debt in China. Source: Business insider UK (Moshinsky, 2015; Lopez, 2015).

their debts. Huas International Group, a famous real estate developer, was unable to pay their debts which involve more than 5 billion yuan (Sohu, 2016). Another big Chinese cement company, Shanshui Group, defaulted on two-billion-yuan (\$314 million, £207 million) domestic payment (Business Insider: Moshinsky, 2015; Lopez, 2015). What's more, the state-owned Dongbei Special Steel Group Co. recently announced that it will not be able to get enough money to meet the RMB700 million debts (Caixin, 2016). All these default cases interpret a harbinger of bigger problems to come in China.

\subsubsection{Huas International Group (Holdings) Company. Ltd}

Huas International Group was established in 1993, and has become one of the most influential enterprises in the private economy of Hubei province, and also one of the top ten private enterprises in Hubei province. In 1996, the Group moved to property market, and mainly engaged in real estate development, commercial operations, hotel management, commercial trade, cinema studios, investment guarantees, financial securities, media advertising, property management, and other industries. Now the Group assets have reached six billion yuan. 
On November 26, 2015, Wuhan Wealth Cornerstone Investment Management Co., Ltd which is one of the most influential management companies in Wuhan area, announced that its financial products cannot be honored. Huas International Group was just the real owner behind the Wuhan Wealth Cornerstone Investment Management. In 2015, Huas' project was seized and cannot be sold so that the capital cannot be returned, which directly lead to this payment crisis. This payment crisis involves a total of more than 70 thousand investors and an amount of more than 5 billion yuan. Wuhan Wealth Cornerstone belongs to Cornerstone capital group (Huas international Group is the real one behind), and they use an online and offline dual track operating mode. Currently, there are more than 30 stores across the country, most of which are located in Wuhan city.

According to the Cornerstone online lending platform, we can find that this platform has been on line for 483 days, the total amount of investment is one billion two hundred and fifty-eight million yuan, users total revenue is 19.9 million yuan, the total number of registered user are more than 75 thousand (Sohu, 2016; Wodai, 2015).

Many industry insiders said that many real estate companies set up financial companies to input funds for their projects. However, those financial companies will be bankrupt once there is stagnation in sales and construction. Financial product which seems promising and profitable is actually highly risky.

\subsubsection{Shandong Shanshui Default Case}

Dragged by real estate industry, cement industry was hit by the dramatically decreasing demand. Real estate and infrastructure accounted for approximately $60 \% \sim 70 \%$ in the cement demand, so the increasingly murky situation in real estate industry has great negative effects on cement industry. According to the data from the National Bureau of statistics, from January to April in 2015, the investment in Shandong's real estate development grew by $0.6 \%$, which decreased by 0.2 percentage points compared with the previous three months. Compared with the slow growth in investment, the fall of new projects of real estate is more severe. During the same period, Shandong new construction area of real estate fell by $30.5 \%$. In the first 4 months of this year, Shandong cement production fell by $14.18 \%$, to 4045.6 tons, while it was 4714.3 tons during the same period last year. Although the decreasing demand for cement, it is hard to further reduce the price because the low cost is also hard to reduce. The current cement prices are in the cost line. To reduce losses as far as possible, many companies have chosen to stop production. Now the operating rate of Shandong cement enterprises is about $60 \%$, some are even lower than $50 \%$, lower than the average level of $65 \%$ in previous years.

On November 11, Shanshui Group, as one of the biggest cement companies, has announced that it will not be able to get enough money to meet the domestic debts (Two-billion-yuan ultra-short financial bond) on or before November 12, 2014, and it will certainly face a debt default within the territory. Shanshui 
Group also announced that due to the economic slowdown and the decline of demand in cement market, coupled with overcapacity, China's cement market competition continues to be intense, and there is a decline in both price and production (Bloomberg, 2015).

Up to now, Shanshui Group still has six domestic bonds, and the total debts are 7.1 billion yuan, including the $20 \%$ debt default. These bonds will mature in the next two years, and the 2.6 billion yuan of ultra short integration and medium-term notes need to be honored the first quarter of next year (Business insider UK: Moshinsky, 2015; Lopez, 2015).

\section{Conclusion and Suggestions}

In the past three decades, financial repression has played a leading role in stimulating China's economic growth. The main goal of China's financial repression policy is to support and encourage state-owned enterprise (SOEs) by providing cheap loans to them through paying very low saving rate to depositors. Under this policy, state-owned enterprises are one of the biggest beneficiaries. They can easily get founds from large state-owned banks with the help of government assistance and support than private enterprises. Banks are also one of the beneficiaries, but their gains are limited because they have to meet the high reserve requirement and pay for central bank bills. Government can also benefit a lot because it is able to spend less maintaining a fixed and undervalued exchange rate through the central bank than adopting a more liberalized interest rate mechanism. As a result, China was able to rely on saving-financed investments for economic growth, and governments were able to finance themselves at this artificially low interest rate at the same time.

The fact reflects that the desire of regulators to eliminate internal and external risk by employing political financial policies to guide domestic investment incentives could lead to the creation of a high level of risk for financial market. Usually, repression policy led to more desire of housing purchase, and the overheated housing market attracted more loans and credit from banks and other nonbanking financial system. Nowadays, a lot of evidence shows that, with interest rates lower than inflation rate and strictly controlled equity market, Chinese households and enterprises were all stimulated to invest in housing to accumulate and maintain their net worth because housing values keep pace with inflation and do not fluctuate as widely as does the value of other investments, and in rapidly urbanizing countries housing has historically had a high and stable rate of return. By motivating housing speculation, financial repression also fueled an expansion in debt which makes Chinese banks quite risky. The fact is that loans to companies and households of gross domestic product (207\%) at 2015 have already much higher than Greek debt (185\%).

Therefore, we have reasons to believe, according to the data of these years, that repression policy has caused potential debt crisis for banks. Once the housing market cools down, enterprises and household will have great difficulties paying their mortgage loan debts, and banks will suffer a lot like what happened 
in the U.S 2008. China's local government relies too much on the out-of-budget income which is even much higher than government's budget income such as taxes and fees. However, land finance is not a long-term strategy current situation where housing market is overheated and domestic economy shows downward trend. Thus, reducing cost burdens or enlarging revenue source should be the main goals for China's local government. Employing property tax could be a good choice for local government, which can provide a stable stream of local tax revenues.

Therefore, we suggest Chinese government relax its financial repression policy to make domestic economic and investment environment more consistent with international environment. Higher level of economic liberalization is urgently required. As Dorn (2006: 3) pointed out in his economic analysis, "economic liberalization, privatization, and free-market competition are the only effective means to expand individual choices, and hence, to develop". Thus, Chinese government should focus more on the issue of capital freedoms, such as further open its capital market, use domestic monetary policy to achieve long-run price stability. Fortunately, Chinese policy makers have already realized the importance of economic liberalization as well as capital freedom, and they began to consider exchange rate reform and banking system reform.

Chinese government could also resort to property tax as a new way to cool down the overheated housing market, and also as a new way of local government financing. In the U.S, property taxes are a fundamental source of revenue for local governments, constituting $73 \%$ of local government tax revenue in the United States (Tsoodle \& Turner, 2008). The property tax in the US, about $1 \%$ of the capital value of a home, is much higher than other OECD countries like Italy which is only $0.25 \%$ (Evans, 2012). Also the property tax is imposed on both owner occupied and tented housing. Many scholars have investigated the impact of property taxes on the house price and proved that it can cool down the housing market, such as Oates (1969) who finds that property taxes and the value of public services are capitalized into house prices. Yinger et al. (1988) also generated their estimation that for every $\$ 1$ increase in the present value of the stream of property tax payments on the house, the house value is declined by 16 cents to 31 cents. On the one hand, Chinese local government is able to obtain stable and long-term revenue by levying property taxes, which then will reduce its desire of leasing more land and gaining profits from formal and informal processes. Land price will decline accordingly by then. On the other hand, property taxes can impede the increasing housing demand to some extent. In the short run, the stock of housing is fixed, but employing a property tax decreases the consumer's willingness to pay for new or expanded housing. Therefore, the decrease of housing demand leads to the fall of housing price. Furthermore, it increases the cost of moving because transaction cost it too large. Households may find it difficult to meet the extra tax payments out of their current income, of to obtain a bank loan (Englund, 2003). Finally, the housing price could be controlled and the housing market could be cooled down. 
What's more, issuing more government bonds and opening bond market more is another choice for local government to enlarge their revenue source, and for private enterprises to raise funds as well as solve housing problems. Currently, China's bond market is still at primitive stage and illiquid, it is not a global play as well. In China, bonds are usually purchased by the investment bank as a whole at the agreed prices, and then sold to investors at higher prices. However, many bonds are not in circulation in secondary market. Thus, banks actually bear the risk (Zhang, 2016). Thus, it is very important to improve China's bond market now. If government and SOEs issue more bonds, and banks sale more discounted note, on the one hand, government can obtain more money to make investment or meet their expenditure. On the other hand, when those bonds are circulated in secondary market, banks could lend more money to people to start business, then the money is recapitalized and banks can also get rid of bad debts.

Although existing proofs indicate the apparent bank credit risk, there is no definite answer for whether China's overheated housing market will be followed by debt crisis in the near future. China is currently in a dilemma. On the one hand, the prosperity is of great significance for both government finance and economy growth. On the other hand, debt crisis could be induced by the overheated housing market. In recent years, Chinese central government and municipal governments are always adjusting strategies and making related housing policies and tight monetary policies to cool down the housing market and combat housing speculation in order to prevent the further growth of housing price and happening of possible financial crisis. However, how to go out of this dilemma is still a hardest issue for China and needs further discussion in future research.

\section{References}

Batra, G., Kaufmann, D., \& Stone, A. H. (2002). Voices of the Firms 2000: Investment Climate and Governance Findings of the World Business Environment Survey (WBES).

Borst, N., \& Lardy, N. (2015). Maintaining Financial Stability in the People's Republic of China during Financial Liberalization. Peterson Institute of International Finance. https://doi.org/10.2139/ssrn.2588543

Bloomberg (2015). China's Latest Default Foretold in Creditors Calling CFO Nonstop. https://www.bloomberg.com/news/articles/2015-11-11/china-s-shanshui-cement-to-de fault-on-onshore-bonds-on-thursday

Bloomberg (2016). China Default Chain Reaction Looms Amid 192 Day Cash Turnaround.

Caixin (2016). Rash of Debt Defaults Should Spur Regulators to Act. http://english.caixin.com/2016-05-11/100942211.html

Campanella, M. L. (2016). Financial Repression and the Debt Build-up in China: Is There a Way Out? European Centre for International Political Economy. Available from: http://ecipe.org/app/uploads/2016/06/PB_05_2016_V3.pdf (Accessed 14 June)

Dobbs et al. (2015). Debt and (Not Much) Deleveraging. Finweek. http://www.mckinsey.com/global-themes/employment-and-growth/debt-and-not-muc 
h-deleveraging

Dorn, J. A. (2006). Ending Financial Repression in China 1. Global Economic Review, 35, 231-238. https://doi.org/10.1080/12265080600715566

Englund, P. (2003). Taxing Residential Housing Capital. Urban Studies, 40, 937-952. https://doi.org/10.1080/0042098032000074254

Evans, A. W. (2012). Optimal Tax Theory and the Taxation of Housing in the US and the UK. Journal of Property Research, 29, 368-378. https://doi.org/10.1080/09599916.2012.730054

Government UK (2014). China's Debt-Latest Assessment, December 17, Available from: https://www.gov.uk/government/publications/chinas-debt-latest-assessment (Accessed 18 May 2017)

Giovannini, A., \& Melo, M. D. (1990). Government Revenue from Financial Repression (Vol. 83, pp. 953-963). The World Bank.

ICBC (2008). Annual Report 2008, March 13.

ICBC (2011). Annual Report 2011, March 15. Available from: http://www.icbc-ltd.com/icbcltd/investor\%20relations/financial\%20information/financ ial\%20reports/ (Accessed 15 April 2017)

ICBC (2014). Annual Report 2014, March 26.

ICBC (2016). Annual Report 2016, March 30. Available from: http://v.icbc.com.cn/userfiles/Resources/ICBCLTD/download/2016/7201520160422.pd $\underline{\mathrm{f}}$ (Accessed 16 April 2017)

IMF (2013). Transition Challenges to Stability. Available from: http://www.imf.org/en/publications/gfsr/issues/2016/12/31/transition-challenges-to-sta bility (Accessed 18 April 2017)

IMF (2016). Potent Policies for a Successful Normalization Global Financial Stability. http://www.imf.org/en/publications/gfsr/issues/2016/12/31/potent-policies-for-a-succe ssful-normalization

Johansson Anders, C. (2012). Financial Repression and China's Economic Imbalances. Stockholm School of Economics CERC Working Paper. https://ideas.repec.org/p/hhs/hacerc/2012-022.html

Lardy, N. (2008). Financial Repression in China. Peterson Institute for International Economics Policy Brief, September.

Lardy, N. R. (2008). Financial Repression in China. Policy Briefs. https://doi.org/10.2139/ssrn.2126174

Lopez, L. (2015). Chinese Companies Keep Giving Crazy Reasons for Losing Their Financial Records. Business Insider UK December 31. Available from:

http://uk.businessinsider.com/chinese-company-records-taken-by-gang-2015-12 (Accessed 14 June 2017)

Moshinsky, B. (2015). Chinese Companies Are Starting to Default on Their Debt. Business Insider UK November 11. Available from:

http://uk.businessinsider.com/chinese-shanshui-cement-corporate-default-2015-11 (Accessed 14 June 2017)

Oates, W. E. (1969). The Effects of Property Taxes and Local Public Spending on Property Values: An Empirical Study of Tax Capitalization and the Tiebout Hypothesis. Journal of Political Economy, 77, 957-971. https://doi.org/10.1086/259584

PBC (2010). Annual Report 2010, June 24. Available from: http://v.icbc.com.cn/userfiles/Resources/ICBCLTD/download/2016/7201520160422.pd 
f (Accessed 18 April 2017)

Renaud, B. (1988). Compounding Financial Repression with Rigid Urban Regulations: Lessons of the Korean Housing Market. Review of Urban \& Regional Development Studies, 1, 3-22. https://doi.org/10.1111/j.1467-940X.1989.tb00001.x

Sohu (2016) Reveal the Secret of the Bankruptcy of the Wealth Cornerstone and Other Wealth Management Companies for You. http://chihe.sohu.com/20160115/n434686335.shtml

Schnabl, G. (2012). Monetary Policy Reform in a World of Central Banks. https://doi.org/10.2139/ssrn.1998092

Shih, V. (2004). Dealing with Non-Performing Loans: Political Constraints and Financial Policies in China. The China Quarterly, 180, 922-944.

https://doi.org/10.1017/S0305741004000682

The World Bank (2012). Database. The World ibrad.ida

Tsoodle, L. J., \& Turner, T. M. (2008). Property Taxes and Residential Rents. Real Estate Economics, 36, 63-80. https://doi.org/10.1111/j.1540-6229.2008.00207.x

Wodai (2015). Wuhan Cornerstone Was Reported Hard to Pay, 1000 Debt Collector Came down on the Company.

http://www.wodai.com/n_zhuanlan/atrcle_71253.html

Yinger, J., Bloom, H. S., Börsch-Supan, A., \& Mills, E. S. (1988). Property Taxes and House Values.

Zhang, L. (2016). A Summary of Literature: Convertible Bond Issue Announcement Effect. American Journal of Industrial \& Business Management, 6, 83-88.

https://doi.org/10.4236/ajibm.2016.62007 